\title{
KEBIJAKAN PEMBERITAAN KANTOR BERITA ANTARA DI ERA KONVERGENSI MEDIA
}

\author{
Meti Nurhayati \\ Univetsitas Gunadarma, Depok, Indonesia \\ meti2911@staff.gunadarma.ac.id
}

Submitted: 19-11-2021, Revision: 14-12-2021, Accepted: 29-12-2021

\begin{abstract}
This research on the work of the ANTARA News Agency uses a qualitative research approach. The phenomenological method and using critical discourse analysis on news text framing, the study focused on how ANTARA framed its news in the Reformation era and media convergence (from 1998 to the present) by paying attention to news framing in the previous era (Old Order and New Order eras). to sharpen research. This study seeks to explore comprehensive information about how ANTARA's news framing was during the reform era and the era of media convergence, by paying attention to how the same policies in the previous government (the New Order era) sharpened the focus of the research. The results of the study indicate that press coverage, including ANTARA during the New Order era, followed the policies of the authorities, but also contributed to the creation of national stability and the establishment of the Unitary State of the Republic of Indonesia (NKRI) because it did not broadcast news on SARA issues. Meanwhile, during the reformation period, the nuances of the "national vision" or ideology of the mass media, including ANTARA, tended to diminish. In accordance with its historical role for the state, ANTARA in the future can and needs to carry out the function of press diplomacy in an effort to improve Indonesia's image in the international world. Meanwhile, ANTARA's true dedication and loyalty is not to the government (the rulers), but to the state, in this case the Unitary State of the Republic of Indonesia.
\end{abstract}

Keywords: New Order, Reformation Era, Media Convergence, News Framing

\begin{abstract}
Abstrak
Penelitian tentang kiprah Kantor Berita ANTARA ini menggunakan pendekatan penelitian kualitatif. Metode fenomenologi dan Menggunakan analisis wacana kritis pada framing teks berita, Penelitian difokuskan pada bagaimana ANTARA memframing (membingkai) pemberitaannya pada era Reformasi dan konvergensi media (tahun 1998 hingga saat ini) dengan memperhatikan framing pemberitaan pada era sebelumnya (era Orde Lama dan Orde Baru) untuk menajamkan penelitian. Penelitian ini berupaya menggali informasi yang menyeluruh tentang bagaimana framing pemberitaan ANTARA pada era pemerintahan di masa reformasi dan era konvergensi media, dengan memperhatikan bagaimana kebijakan yang sama pada masa pemerintahan sebelumnya (era Orde Baru) untuk menajamkan fokus penelitian. Hasil dari penelitian mengindikasikan bahwa pemberitaan pers, termasuk ANTARA di masa Orde Baru lebih banyak mengikuti kebijakan penguasa, namun turut memberikan andil bagi terciptanya stabilitas nasional dan terbinanya Negara Kesatuan Republik Indonesia (NKRI) karena tidak menyiarkan pemberitaan masalah SARA. Sementara itu di masa reformasi, nuansa "visi kebangsaan" atau ideologi media massa, termasuk ANTARA cenderung berkurang. Sesuai peran kesejarahannya bagi negara, ANTARA ke depan dapat dan perlu melaksanakan fungsi diplomasi pers dalam upaya meningkatkan citra Indonesia di dunia internasional. Sementara itu dedikasi dan loyalitas ANTARA sejatinya adalah bukan kepada pemerintah (penguasa), melainkan harus kepada negara, dalam hal ini NKRI.
\end{abstract}

Kata Kunci: Orde Baru, Era Reformasi, Konvergensi Media, Framing Pemberitaan 


\section{PENDAHULUAN}

Lembaga Kantor Berita Nasional (LKBN) ANTARA selanjutnya dalam penelitian ini disebut ANTARA yang didirikan di Jakarta pada 13 Desember 1937 adalah salah satu dari tiga kantor berita nasional yang ada di Indonesia. Keberadaannya bisa dipertahankan sejak zaman perjuangan kemerdekaan hingga saat ini.

Kantor berita itu didirikan oleh empat serangkai pejuang kemerdekaan, yakni Adam Malik, Soemanang, Pandu Kartawiguna, dan AM Sipahutar. Dua kantor berita lainnya adalah Kantor Berita Nasional Indonesia (KNI) dan Pemberitaan Angkatan Bersenjata (PAB), namun keberadaan dua kantor berita yang disebut terakhir saat ini tidak jelas. ANTARA didirikan untuk menjembatani kepentingan rakyat dan para pejuang kemerdekaan Indonesia dan proklamasi kemerdekaan tanggal 17 Agustus 1945 disiarkan ke seluruh dunia oleh ANTARA, sehingga Indonesia kemudian segera mendapatkan pengakuan internasional. Saat ini kantor berita tersebut berperan menjembatani kepentingan rakyat dengan pemerintah atau sebaliknya melalui pemberitaan.

Selain memproduksi serta menjual berita dan foto kepada media cetak dan elektronik serta instansi pemerintah dan asing di Indonesia, ANTARA juga melakukan kerjasama operasi dengan mitra asing, yakni Reuters (Kantor Berita Inggris) dan perusahaan penyedia real-time data lainnya, yakni Bloomberg (perusahaan Amerika). Sejak kantor berita itu didirikan pada 13 Desember 1937 atau sebelum Indonesia merdeka, para pejuang kemerdekaan dari kantor berita tersebut ingin memajukan kesejahteraan umum melalui kebebasan berpendapat dan berserikat.

Oleh karena itu setelah Indonesia merdeka, Presiden Soekarno mengambil peran dan fungsi ANTARA untuk dijadikan bagian dari alat perjuangan RI melalui
Kepres No. 307 tahun 1962 yang disempurnakan oleh Orde Baru melalui Keppres No 85 Tahun 1966. Intinya adalah ANTARA ditempatkan di bawah kendali Presiden. Kemudian UU No 40 Tahun 1999 tentang Pers yang terbentuk setahun setelah kelahiran Orde Reformasi mendorong lahirnya UU Penyiaran No 32 Tahun 2002 yang menjadi dasar dari pembentukan Lembaga Penyiaran Publik (LPP) RRI dan TV RI yang berada langsung di bawah Presiden atas usulan DPR.

Posisi ANTARA tidak dimasukkan dalam UU Penyiaran, tetapi juga tidak dibuatkan payung hukumnya dalam bentuk undang-undang. Oleh karenanya, agar kantor berita itu tidak mengalami "penutupan" sebagai dampak dari perubahan politik, maka ANTARA dimasukkan ke dalam UU BUMN No 19 Tahun 2003. ANTARA dianggap memenuhi syarat dijadikan Perusahaan Umum (Perum) dengan anggaran operasional lewat Public Service Obligation (PSO). Namun demikian kedudukan hukum PP No 40 Tahun 2007 sebagai dasar pembentukan Perum LKBN ANTARA tidaklah sejajar dengan perusahaan pers milik negara lainnya, yaitu RRI dan TVRI. ANTARA kenyataannya berada di bawah Menteri BUMN yang diarahkan untuk mencari keuntungan, sementara kedua stasiun pemberitaan lainnya tidak difokuskan memperoleh keuntungan. Mereka berusaha sebagai perusahaan nir laba dan berada di bawah kendali Presiden.

Atas dasar itulah diperlukan kajian hukum untuk mengembalikan kelembagaan ANTARA di bawah Presiden dalam upaya mengoptimalkan fungsi dan peran persnya sesuai eksistensinya sebagai kantor berita nasional. Pada akhirnya, bentuk badan hukum juga sedikit banyak akan mempengaruhi strategi, termasuk framing pemberitaannya depan. Dalam kaitan itu ANTARA sudah selayaknya dikembalikan marwahnya untuk menjadi lembaga yang berada langsung di bawah Presiden agar 
kedudukan ANTARA menjadi lebih kuat sebagai kantor berita negara dalam berperan sebagai "flag carrier" untuk kepentingan bangsa dan negara.

Argumentasi pokok dari teori elite ini adalah bukan rakyat yang menentukan kebijaksanaan (atau kebijakan) publik melalui tuntutan-tuntutan dan tindakan mereka, tetapi elite yang memerintah dan dilaksanakan pejabat-pejabat serta badanbadan pemerintah. Sesuai dengan hal di atas, pemerintah mempunyai tanggung jawab yang sangat besar terhadap masyarakat/publik dalam menetapkan hukum dan kebijakan sesuai dengan aturan yang berlaku, termasuk kebijakan di bidang pers. Pengambilan kebijakan yang dilakukan pemerintah untuk kepentingan publik harus didasarkan pada prinsip keadilan dan demokrasi.

Kebijakan publik adalah keputusankeputusan yang mengikat bagi orang banyak pada tataran strategis atau bersifat garis besar yang dibuat oleh pemegang otoritas publik. Sebagai keputusan yang mengikat publik, maka kebijakan publik haruslah dibuat oleh otoritas politik, yakni mereka yang menerima mandat dari publik atau orang banyak, umumnya melalui suatu proses pemilihan untuk bertindak atas nama rakyat banyak. Selanjutnya, kebijakan publik akan dilaksanakan oleh administrasi negara dan dijalankan oleh birokrasi pemerintah. Fokus utama kebijakan publik dalam negara modern adalah pelayanan publik, yang merupakan segala sesuatu yang bisa dilakukan oleh negara untuk mempertahankan atau meningkatkan kualitas kehidupan orang banyak. Kebijakan publik juga berfokus pada upaya menyeimbangkan peran negara yang mempunyai kewajiban menyediakan pelayan publik dengan hak untuk menarik pajak dan retribusi; dan pada sisi lain menyeimbangkan berbagai kepentingan kelompok dalam masyarakat dengan berbagai kepentingan negara sesuai amanat konstitusi.
Salah satu dari kebijakan publik yang amat penting bagi masyarakat adalah kebijakan komunikasi. Lalu secara lebih fokus, bagaimana sebenarnya kebijakan komunikasi itu? Sebagai kebijakan publik, maka kebijakan komunikasi jelas harus dirumuskan oleh pemerintah. Lalu lembaga pemerintah mana yang berhak merumuskan kebijakan komunikasi? Jawaban yang masuk akal adalah tergantung kepada jenis kebijakan komunikasi yang dibicarakan. Di Indonesia, pada saat kebijakan komunikasi berbentuk Undang-undang, ia sudah terlebih dahulu dibahas oleh Dewan Perwakilan Rakyat (DPR) dan mendapat persetujuan pemerintah. Tanpa persetujuan DPR dan pemerintah, sebuah undang-undang tentang komunikasi tidak akan bisa berlaku efektif. Maka kebijakan komunikasi dalam bentuk undang-undang merupakan produk bersama antara pemerintah dan DPR.

Adapun jenis-jenis kebijakan komunikasi, sesuai peraturan perundangundangan yang berlaku di Tanah Air bisa berbentuk Undang-undang, Peraturan Pemerintah, Keputusan Presiden, Instruksi Presiden, Surat Keputusan Menteri, Peraturan Menteri, dan Peraturan Daerah. Adapun sumber kebijakan komunikasi di Indonesia ada dua, yakni Undang-undang Dasar Tahun 1945 dan nilai-nilai moral yang ada dalam kehidupan sosio-kultural masyarakat. Ditinjau dari sisi sosiologi, tujuan kebijakan komunikasi adalah menempatkan proses komunikasi sebagai bagian dari dinamika sosial yang tidak merugikan masyarakat, dan masyarakat pula yang seharusnya mengendalikan proses komunikasi yang terjadi di antara mereka. Kalaupun pemerintah menjadi pembuat kebijakan komunikasi, perannya tidak lebih sebagai fasilitator.

Dalam kaitan dengan kebijakan komunikasi, Paula Chakravartty dan Katharine Sarikakis menjelaskan bahwa kebijakan komunikasi tidak bisa dipisahkan dari perkembangan sosial, politik, dan ekonomi sebuah negara. Lebih dari itu, 
kebijakan komunikasi selalu memiliki konteks, domain dan paradigma (Chakravarty et al., 2016) Konteks berarti keterkaitan kebijakan komunikasi dengan sesuatu yang melingkupi dirinya, misalnya politik-ekonomi dan politik-komunikasi. Konteks ini sangat penting bagi kebijakan komunikasi. Ia menentukan domain kebijakan komunikasi. Domain kebijakan komunikasi itu sendiri bermakna muatan nilai yang dikandung kebijakan komunikasi seperti globalisasi atau ekonomi global atau pasar. Ia bisa disebut fungsi konteks kebijakan komunikasi. Karena konteksnya politik-ekonomi misalnya, maka domain kebijakan komunikasinya adalah ekonomi global.

Sementara itu paradigma berarti kerangka cita-cita yang menjadi tujuan kebijakan komunikasi seperti terbentuknya masyarakat informasi atau menguatnya civil society. Secara umum paradigma bisa bertolak dari bagaimana masalah yang dihadapi masyarakat bisa terselesaikan. Ketiga aspek kebijakan komunikasi ini sangat diperlukan untuk mengetahui lebih jauh serta untuk menganalisis sebuah kebijakan komunikasi. Pengetahuan tentang ketiganya sangat berguna untuk menilai apakah sebuah kebijakan komunikasi masih tetap berlaku atau sudah saatnya diganti. Dalam prakteknya kebijakan komunikasi tidak selalu terumuskan dengan jelas dan spesifik. Setelah dirumuskan pun bentuknya tidak selalu berupa Undang-undang, tetapi bisa saja Surat Keputusan Menteri, Peraturan Daerah dan sebaginya. Kendati begitu, kebijakan komunikasi selalu menjadi panduan berbagai pihak dalam berkomunikasi.

Pihak-pihak dimaksud meliputi birokrat, masyarakat, dan praktisi media. Tegasnya, kebijakan komunikasi mempengaruhi kegiatan komunikasi masyarakat, lembaga dan kaum profesional. Khusus di lembaga pers berlaku apa yang disebut dengan "kebijakan pemberitaan" yang kecenderungannya banyak dipengaruhi oleh ideologi media atau oleh pemilik media yang bersangkutan atau oleh pasar, terlebih di era konvergensi media sekarang ini.

Upaya memahami suatu relitas merupakan aktivitas individu yang terkoordinasi dan mengikuti proses pertukaran yang menjadi karakteristik setiap interaksi manusia. Makna yang diproduksi dan diterima pelaku sosial merupakan bentuk pemahaman dirinya terhadap suatu realitas. Makna tersebut dikonstruksi atau dibentuk secara sosial. Suatu realitas tidak dapat diterima begitu saja oleh setiap pelaku sosial. Apa yang mungkin dianggap nyata oleh setiap individu akan menjadi nyata dalam benaknya. Realitas terdiri dari keyakinan-keyakinan dan asumsi-asumsi yang dibagi dalam kelompok-kelompok. Realitas kehidupan sehari-hari merupakan sebuah realitas yang utama. Menurut Schutz berbagai realitas eksis, tetapi mereka diturunkan dari realitas yang utama (Berger, 2016)

Realitas bersifat elastis. Artinya tidak ada realitas tunggal yang lebih benar daripada realitas lainnya, sehinga cara terbaik melihat realitas adalah melihatnya kepada diri sendiri. Akhirnya, Schutz pun menegaskan, "Forms of life are always forms of life forming. Realities are always realities becoming." Dalam kenyataannya tidak semua realitas sosial dapat dikonstruksi oleh media. Alasannya, tidak semua media massa memiliki intensitas yang sama dalam mengkonstruksi realitas sosial. Konstruksi sosial realitas, karena menyangkut makna, dengan sendirinya sangat erat dengan kesadaran (Berger, 2016).

Dengan kata lain kesadaran setiap individu pelaku sosial terhadap realitas merupakan bagian penting dalam konstruksi sosial. Berdasarkan kerangka pemikiran Karl Marx, para kapitalis media sering "mempermainkan" kesadaran masyarakat melalui konstruksi realitas sosial yang telah diubah citranya. Akibatnya, 
kesadaran masyarakat terhadap realitas sosial merupakan kesadaran palsu.

Framing merupakan salah satu cara untuk mengetahui sekaligus membuktikan bahwa realitas sesungguhnya merupakan hasil konstruksi (baik konstruksi individu, masyarakat maupun media). Dalam pemahaman beberapa ahli, framing adalah cara untuk melihat bagaimana realitas itu dibentuk dan dikonstruksikan oleh media. Secara praktis framing dapat dipahami sebagai cara bagaimana peristiwa atau realitas disajikan oleh media. Cara penyajian tersebut secara umum memiliki dua dimensi dalam framing. Pertama, seleksi isu. Dalam menyajikan sebuah peristiwa wartawan atau awak media telah melakukan pemilihan terhadap fakta di lapangan dengan asumsi bahwa pekerja media tidak mungkin melihat peristiwa tanpa perspektif. Kedua, penekanan isu. Hal ini dapat teramati bagaimana pekerja media menuliskan fakta dan proses ini berhubungan dengan bagaimana fakta yang dipilih disajikan kepada khalayak.

Seperti diungkapkan oleh Frank D. Durham (Eriyanto, 2011) framing membuat dunia lebih diketahui dan lebih dimengerti. Dengan framing realitas yang begitu rumit dan kompleks disederhanakan oleh media sehingga mudah dipahami serta diingat dan realitas tersebut lebih bermakna dan relatif mudah dimengerti. Kajian atas konstruksi (framing) berita dalam media sangat erat kaitannya dengan derajat atau bahkan nilai subjektivitas media itu sendiri atau kebijakan manajemen medianya, sehingga paling tidak, tidak ada media yang objektif dan yang ada adalah berita karakteristik media masing-masing.

Dengan memahami konstruksi realitas sosial dan pisau analisis framing, penelitian tentang pemberitaan dan kiprah Kantor Berita ANTARA ini kemudian akan memakai paradigma konstruktivisme. Ibnu Hamad menyebutkan bahwa dalam paradigma konstruktivis, data dan informasi "bersifat subyektif" dalam arti didasarkan atas pandangan pihak yang diteliti. Mereka (yang diteliti) diperlakukan sebagai subyek penelitian yang memiliki pandangan tertentu atas apa yang menjadi perhatian si peneliti. Dengan demikian, data dalam paradigma kontruktivis harus mencerminkan apa yang dirasakan dan yang ingin disampaikan oleh pihak yang diteliti (subyek penelitian), dan bukan apa yang ingin diceritakan oleh si peneliti, sehingga di sini peneliti mesti menyelami alam fikiran subyek penelitian agar diperoleh perspektif yang bersifat subyektif tersebut (Hamad, 2004)

Adapun penelitian terdahulu sebagai landasan dari penelitian ini adalah pertama penelitian yang berjudul "Konvergensi Konten Majalah Popular dalam Industri Digital Media Cetak", oleh Citra Eka Putri, yang menjelaskan terkait Perkembangan tekonologi komunikasi saat ini yang bertumbuh pesat, berpengaruh pada industri media cetak. Sejumlah media cetak di Indonesia mulai tutup karena tidak mampu bersaing dengan media digital lainnya, sehingga pengelola media cetak melakukan berbagai upaya untuk mempertahankan eksistensi medianya dengan melakukan convergensi, dan menyiapkan media berbasis digital, salah satunya Majalah pria dewasa "Popular". Tujuan penelitian ini adalah untuk mengetahui upaya yang dilakukan oleh majalah Popular dalam mempertahankan hidupnya sebagai jawaban atas perkembangan tekhnologi industri informasi media. Hasil penelitian ini menunjukkan, majalah Popular menempuh model konvergensi Content dan tampil di berbagai platform sosial dengan satu tujuan: mempertahakan eksistensi keberadaan majalah Populer dalam industri Media Massa (Putri \& Hamzah, 2018).

Penelitian terdahulu kedua adalah penelitian yang berjudul, Media Convergence of Local Newspapers: Descriptive Study of Internet Utilization in Jogja Tribune Newspapers in Building Local Print Media Industry. (Konvergensi Media Surat Kabar Lokal: Studi Deskriptif 
Pemanfaatan Internet Pada Koran Tribun Jogja), oleh Khadziq pada jurnal komunikasi yang isinya menjelaskan Persaingan media dan perkembangan Teknologi Informasi dan Komunikasi (TIK) yang membawa tren baru dalam dunia industri komunikasi. Instrument untuk menghadapinya adalah konvergensi yang berorientasi pada kepentingan konsumen dan pemilik media. Media yang telah terkonvergensi juga berpengaruh terhadap besarnya kepentingan ekonomi politik dalam penerapan konvergensi. Pengumpulan datanya dilakukan dengan cara observasi dan wawancara mendalam serta kajian literatur. Hasil analisis deskriptif menunjukkan bahwa strategi 3M (Multimedia, Multichannel dan Multiplatform) digunakan Tribun Jogja menjadi salah satu alternative strategi untuk menerapkan konvergensi dan mentransformasikan dirinya menuju full convergence.

Sedangkan pada ekonomi politiknya terlihat bahwa melalui penerapan konvergensi media ini, maka dengan komodifikasi yaitu adanya pengambilan dan penyeragaman konten di antara sesama media yang berada dibawah jaringan Tribun akan mendapatkan keuntungan melalui pasokan pengiklan, begitu pula spasialisasi yang memungkinkan penyaluran konten berita secara realtime dapat mengurangi biaya tenaga kerja, administratif, dan material. Kesimpulan dari penelitian ini adalah konvergensi yang dilakukan adalah konvergensi kontekstual yaitu konvergensi yang disesuaikan dengan kebutuhan dan kondisi budaya perusahaan dan masyarakat. Ini terbukti konvergensi dapat terlaksana tanpa melakukan perubahan radikal dengan menyatukan newsroom cetak dan online, media sudah dapat melakukan konvergensi. Kata-kata kunci: Konvergensi media, Rangkaian Konvergensi, Ekonomi politik media dan Tribun Jogja (Khadziq, 2016).

Berdasarkan latar belakang penelitian sebagaimana dijelaskan di atas, tujuan penelitian ini adalah untuk mengetahui bagaimana strategi pemberitaan ANTARA dan bagaimana bentuk badan hukumnya yang paling cocok di era konvergensi media dan era digital saat ini. Oleh karena itu kebijakan publik (hasil dari perdebatan panjang yang bermuatan kepentingan politik) digunakan sebagai alat efektif yang dapat menempatkan posisi aktor dalam kekuasaan konsentrik. Wright Mills, dalam bukunya The Power Elite (1959) mengemukakan bahwa menurut perspektif teori elite, kebijaksanaan (atau bahkan) kebijakan publik dapat dipandang sebagai nilai-nilai dan pilihan-pilihan dari elite yang memerintah.

\section{METODOLOGI}

Penelitian tentang kiprah Kantor Berita ANTARA ini menggunakan metode penelitian kualitatif. Penelitian difokuskan pada bagaimana ANTARA memframing (membingkai) pemberitaannya pada era Reformasi dan konvergensi media (tahun 1998 hingga saat ini) dengan memperhatikan framing pemberitaan pada era sebelumnya (era Orde Lama dan Orde Baru) untuk menajamkan penelitian. Penelitian tentang media massa dan politik, termasuk ideologi media massa berada pada tataran "sebaiknya", "seharusnya", das sollen yang karenanya normative-subjective.

Kelemahan tersebut membangun pandangan berdasarkan asumsi-asumsi ideologis dan sangat potensial untuk kurang sempurna dalam melihat realitas yang sesungguhnya atau justru menutup mata terhadap realitas dan perubahan yang berlangsung dalam realitas tersebut. Pada titik inilah penelaahan teks media melalui analisis framing (analisis bingkai) dalam penelitian disertasi tentang Kantor Berita ANTARA ini menjadi relevan. Analisis framing adalah bagian dari analisis wacana dengan menjadikan teks media sebagai fokus penelaahan.

Dalam tradisi penelitian kualitatif terdapat sejumlah teori (sering juga disebut pendekatan) yang menjadi landasan 
penelitian kualitatif seperti fenomenologi, interaksi simbolik (yang salah satu variannya adalah dramaturgi), etnometodologi, kajian budaya, feminisme, posmodernisme, dan teori kritis. Maka, standarnya pun berbeda-beda, tergantung pada pendekatannya. Penggunaan perspektif teoritis tertentu jelas akan mempengaruhi metode penelitiannya. Deddy lebih lanjut menjelaskan, fenomenologi menitikberatkan pada wawancara mendalam, sedangkan interaksi simbolik dapat menggunakan kombinasi wawancara mendalam dan pengamatan berperanserta. (Mulyana, 2018)

Di sisi lain teori dramaturgis lebih menekankan pengamatan dibanding wawancara. Baik penelitian fenomenologi maupun interaksi simbolik dapat menggunakan dokumen tertulis, dan bahkan semata-mata dokumen tertulis jika itu memadai. Sementara itu penelitian dengan pendekatan analisis wacana kritis atau analisisi bingkai menjadikan teks tertulis atau visual sebagai bahan penelitiannya, sedangkan wawancara dengan beberapa pihak dapat digunakan untuk memperkaya analisis data. Dalam kaitan itu pula penelitian tentang kebijakan pemberitaan ANTARA ini memfokuskan perhatian pada anailis teks berita, sedangkan wawancara diperlukan untuk memperkaya analisis data yang telah dilakukan.

\section{HASIL DAN PEMBAHASAN}

Tidak dapat dipungkiri, teknologi identik dengan kemajuan, kemudahan, dan kecepatan. Saat ini teknologi telah begitu cepat mengantarkan informasi ke ranah publik di mana pun di seluruh dunia. Hanya dalam hitungan menit, penyerangan terhadap World Trade Center (WTC) di New York dan Pentagon di Washington DC Amerika Serikat yang kemudian dikenal sebagai Tragedi 11 September 2001, misalnya, dapat disaksikan secara langsung di seluruh pelosok dunia. Pemirsa televisi di Kalimantan dapat menyaksikan tragedi penyerangan terhadap simbol kekuasaan ekonomi dan militer Amerika Serikat itu sama dengan pemirsa televisi di Jakarta dan Aceh, juga di Beijing, Tokyo, dan di seluruh kota modern di dunia (Lestari et al., 2012)

Tidak puas menonton tayangan informasi di televisi, warga Kalimantan yang memiliki internet dalam waktu singkat dapat mengakses berita-berita seputar tragedi 11 September di berbagai situs media online. Pendengar radio yang berada di mobil dalam kemacetan lalulintas di Jakarta segera pula mengetahui berita menggemparkan itu Dalam kaitan ini Thomas L. Friedman menyadarkan kita bahwa tataran dunia saat ini sudah menjadi datar: "World is Flat". Era teknologi informasi dan komputerisasi yang tengah bergulir telah banyak mengubah konsep bisnis informasi. Teknologi informasi telah menyatu dalam setiap aspek kehidupan manusia dan secara tidak langsung mengharuskan kita untuk memahami serta memanfaatkannya secara optimal (Friedman, 2019). Perkembangan tersebut berlangsung secara global, termasuk di Indonesia.

Informasi sudah menjadi sebuah kebutuhan primer bagi masyarakat dan tidak lagi menjadi barang yang langka. Ia menjadi keniscayaan bagi seluruh aktivitas manusia dalam percaturan global. Sebuah adagium mengatakan, "jika ingin menguasai sebuah negara, maka kuasailah bisnis informasinya", tepat menggambarkan betapa signifikannya bisnis ini. Ranah informasi merupakan sebuah arena bisnis global yang tidak lagi terbentur pada sekat geografis, politis, dan ideologis. Ia sudah menjadi bisnis global yang semakin diperhitungan.

\section{Perkembangan Bisnis Informasi}

Sepanjang yang bisa diamati, ada beberapa alasan mengapa bisnis informasi semakin menunjukkan perkembangannya. Pertama, bisnis informasi semakin mengedepankan kemajuan teknologi yang mutakhir dan sangat membantu efisiensi 
pekerjaan individu. Ranah informasi bukan semata-mata terkait dengan aspek finansial, tetapi juga bersinergi dengan percepatan teknologi yang semakin canggih.

Kedua, bisnis ini juga menunjukkan perkembangan dari segi manajemen. Adanya trend konsolidasi bisnis secara global menjadikan para pemain bisnis ini harus jeli dan responsif membaca pasar yang semakin dinamis. Ketiga, ada kecenderungan kuat bahwa bisnis informasi bukan semata-mata berkaitan dengan aspek ekonomi, tetapi juga dengan ranah sosialpolitik. Indonesia sebagai negara dengan jumlah penduduk yang besar sangat berkepentingan dengan bisnis informasi tersebut. Perkembangan bisnis informasi global juga dialami secara sangat pesat oleh Indonesia. Bahkan, posisi Indonesia tidak kalah pentingnya dibandingkan negaranegara lain. Indonesia memiliki basis SDM berkualitas, sementara pasarnya juga semakin terbuka lebar. Sekedar menyebut contoh adalah pengembangan $e$ government yang gencar dilakukan oleh pemerintah daerah (Damanik \& Purwaningsih, 2018)

Ini merupakan upaya strategis dalam rangka pemerataan informasi dan peningkatan layanan publik yang mempunyai implikasi luas bagi peningkatan kinerja pemerintah, yakni efisien, efektif, dan transparan untuk menciptakan good governance (tata kelola yang baik) serta bagi peningkatan kualitas kehidupan masyarakat. Karenanya, pengembangan informasi terpadu merupakan salah satu kekuatan dan faktor penting yang akan dapat mendorong kemajuan suatu daerah (Damanik \& Purwaningsih, 2018).

\section{Keberadaan Kantor Berita}

Kemudian, bagaimana keberadaan kantor berita di era kemajuan teknologi informasi itu sendiri? Pada awalnya kantor berita hadir untuk melayani sekelompok surat kabar dalam mendapatkan berita dari berbagai tempat. Dalam perkembangannya, kantor berita tumbuh pesat pada awal abad ke-20 yang dimungkinkan dengan adanya kemajuan teknologi berupa telegram serta adanya kondisi pendukung seperti perang, ekspansi industri, dan perdagangan (Barrett, 2015).

Di Amerika Serikat, enam suratkabar mendirikan Associated Press (AP) di New York, Mei 1948. Kantor berita itu pada mulanya merupakan organisasi jejaring berita yang hanya melayani enam surat kabar anggotanya dan menolak memberikan berita untuk surat kabar di luar kelompoknya. Tahun 1943 keadaan itu berakhir setelah keputusan pengadilan menyatakan pembatasan seperti yang dilakukan AP itu adalah pelanggaran terhadap Undang-undang Anti-Trust. Dalam perjalanannya, AP merupakan tantangan pertama bagi dominasi kantor berita Eropa pada awal abad ke-20. Kini AP memiliki 1.600 reporter, editor, dan juru foto serta melayani 1.500 suratkabar, 6.000 stasiun radio dan televisi di Amerika Serikat serta lebih dari 10.000 surat kabar di luar Amerika Serikat (Itule \& Anderson, 2004).

Sementara itu kantor berita transnasional Reuters didirikan di London, Inggris, oleh Paul Julius Reuter pada tahun 1851. Reuters mengirimkan data pasar bursa saham di London dan Paris lewat kabel Calais-Dover dua tahun setelah berdirinya kantor berita itu. Sebelumnya, Paul Julius Reuter menggunakan burung dara untuk mengirimkan harga saham antara Aachen (Jerman) dan Brussels (Belgia). Selama tahun 2005 saja, Reuters Group meraup pendapatan sekitar 2,4 miliar poundsterling, 93 persen di antaranya dari jasa layanan keuangan yang meningkat empat persen per tahun yang dihasilkan dari penyajian data harga realtime (seketika) untuk bank-bank, para pialang, dan pengelola dana investasi.

Dengan motto "Cepat, Akurat, Bebas dari Bias", Reuters menyajikan 5,5 juta data 
real-time bidang keuangan dan informasi tentang 35.000 perusahaan di seluruh dunia. Dalam sehari kantor berita itu menghasilkan data dari sekitar 300 pasar uang dan bursa efek serta 8.000 berita dan 1.000 foto 24 jam per hari dari seluruh dunia. Data keuangan dari berbagai pusat bisnis dunia diperbaharui 8.000 kali per detik, bahkan pada waktu-waktu puncak bisa diperbaharui 23.000 kali per detik (Ferandy, 2016)

Reuters memperluas layanannya ke seluruh dunia dengan jumlah karyawan sebanyak 15.000 orang di 91 negara, 2.300 staf editorial di 196 biro yang tersebar di 130 negara (sekitar 1.800 jurnalis tulis, 300 fotografer, 100 jurnalis TV, dan 160 jurnalis on-line). Kini pelanggan Reuters mencapai 330.000 orang profesional keuangan di seluruh dunia, 1.000 koran dan penerbit di 100 negara, 450 stasiun televisi, dan 12 juta orang mengunjungi situs Reuters tiap bulannya. Berita Reuters itu sendiri disajikan dalam 19 bahasa, dan tiap tahun dilihat dan dibaca oleh sekitar satu miliar orang (Ferandy, 2016)

Dilihat dari sisi sejarahnya, sejak awal sesungguhnya pembentukan kantor berita bermotif ekonomi. Agency Havas, kantor berita yang pertama di dunia, didirikan oleh Charles Havas di Paris tahun 1825. Pada mulanya kantor berita itu menjual berita kepada diplomat, pedagang, dan pengusaha karena surat kabar ketika itu menolak membeli berita dari Havas. Baru sepuluh tahun kemudian, 1835, Agency Havas yang merupakan cikal bakal Agence-FrancePresse (AFP) Perancis menjual berita ke surat kabar setelah berdirinya dua koran $L a$ Presse, dan Le Siecle. Tahun 1940 Havas dibeli dan dikelola pemerintah Perancis di Vichy, sebelum dirampas tentara Jerman.

Selain bermotif ekonomi, motif politik juga menjadi latar belakang pembentukan kantor berita. Di India, beberapa koran terkemuka mendirikan kantor berita The Press Trust of India (PTI) pada tahun 1947 dan mulai beroperasi tahun 1949 untuk melawan penjajah Inggris yang menguasai akses informasi negara itu. Tetapi saat ini, sebagaimana diberitakan Der Spiegel pada April 2009, bisnis sejumlah kantor berita besar dunia tengah berada dalam masa sulit seperti yang dialami Kantor Berita Jerman (DPA). Pada masa lalu DPA adalah tulang panggung banyak media cetak Jerman, tetapi kini semakin banyak saja perusahaan pers yang ragu melangganinya. Bisnis layanan berita terbesar di Jerman itu kini sedang berada dalam masa krisis.

DPA harus memutuskan apakah memilih menjadi pemasok berita yang disubsidi seperti radio-radio pemerintah atau menjadi lembaga jurnalistik berkualitas tinggi yang bergerak lincah di pasar dan membuktikan kemampuannya. Kantor Berita Jerman itu harus membuat dirinya sangat dibutuhkan oleh pelanggan dan berita-beritanya harus lebih cepat, lebih baik, dan lebih cermat.

\section{Tantangan Kantor Berita ANTARA}

Khusus di Indonesia, Pemerintahan Orde Baru selama 32 tahun diakui relatif berhasil membawa perubahan signifikan bagi perekonomian Indonesia, selain juga mampu menciptakan stabilitas politik dan keamanan di dalam negeri. Keberhasilan pemerintahan Soeharto itu dicapai dengan menguasasi tiang-tiang demokrasi yakni eksekutif, legislatif dan yudikatif serta dengan menerapkan pendekatan keamanan.Satu pilar demokrasi lainnya, yakni pers juga dikuasai pemerintahan Soeharto dengan memberlakukan aturanaturan ketat dan keras serta tidak segansegan mematikan pers yang dianggap membandel atau bahkan dinilai melawan pemerintah..

Dengan kondisi seperti itu, maka framing pemberitaan yang tampil ke permukaan adalah pemberitaan yang "baikbaik" saja, sementara berita yang mengkritisi pemerintah dipastikan tidak bisa dimuat media massa, dan dalam keadaan seperti itu berarti undang-undang 
pers menjadi tidak "bergigi". Dari hasil studi kepustakaan tampak bahwa kebijakan Pemerintahan Orde Baru terhadap pers pada periode 1966 hingga 1974 relatif terbuka dan bebas, sehingga masa itu disebut sebagai "masa bulan madu" antara Soeharto dan jajaran pers. Sebelumnya Soeharto membredel sejumlah koran komunis dan melakukan pembersihan besar-besaran terhadap wartawan berhaluan komunis (Ritonga, 2001)

Setelah peristiwa 15 Januari (Malari) 1974 hingga 1988 Pemerintahan Orde Baru mengubah kebijakannya terhadap pers, dari bersikap longgar ke sikap keras, ditandai dengan banyaknya pembredelan surat kabar. Sementara itu sejak 1989 hingga 1998 sikap keras Pemerintahan Orde Baru terhadap pers nasional relatif melunak dan kontrolnya relatif melemah. Sedangkan sejak runtuhnya Orde Baru (sejak 1998 hingga saat ini) pers Indonesia cenderung bebas kebablasan. Pada 1994 Pemerintah Orde Baru melakukan tindakan keras dengan membredel Tempo, Editor dan Detik, namun Pemerintahan Soeharto tidak bisa lagi mengendalikan pers setelah terjadinya revolusi teknologi informasi dengan hadirnya teknologi internet (Ritonga, 2001), Melalui media maya itu rakyat bisa membaca apa saja yang sebelumnya tidak bisa dimuat pers, sementara pemerintah tidak bisa menghambat atau melarang pemakaian internet.

Setelah pembredelan tahun 1994 dan dengan bebasnya berita dan informasi di internet, sebagian kalangan pers mulai melakukan perlawanan kepada Pemerintahan Orde Baru, baik secara terang-terangan maupun melalui gerakan bawah tanah. Pers umum juga mulai berani memberitakan hal-hal sensitif menyusul semakin seringnya terjadi kerusuhan di sejumlah daerah sejak tahun 1995. Pemerintahan di era Orde Baru mengontrol pemberitaan media massa secara ketat dan ANTARA menjadi bagian dari political order pemerintahan saat itu (pemerintahan Presiden Soeharto). Selama pemerintahan Orde Baru, ANTARA memframing pemberitaan melalui penyampaian beritaberita pemerintah yang berisi keberhasilan pembangunan, pidato-pidato pejabat, pengumuman maupun keputusan pemerintah.

Pemberitaan ANTARA di masa Orde Baru lebih banyak mengikuti kehendak atau kebijakan penguasa, namun framing pemberitaan seperti itu turut memberikan andil bagi terciptanya stabilitas nasional dan terbinanya Negara Kesatuan Republik Indonesia (NKRI), sementara di masa Reformasi nuansa "visi kebangsaan" ANTARA cenderung berkurang di tengah iklim kebebasan pers yang cenderung "kebablasan". Krisis ekonomi menjadi momentum bagi rakyat dan mahasiswa untuk memaksa turun Presiden Soeharto dari kekuasaannya pada 1998 dan sejak itu pers Indonesia cenderung mengarah menjadi pers bebas. Departemen Penerangan yang sebelumnya mengatur kiprah pers nasional bahkan dilikuidasi pada era pemerintahan Presiden Abdurrahman Wahid.

Khusus tentang Undang-undang Pers, di masa reformasi terjadi penyempurnaan dengan keluarnya Undang-undang No. 40 Tahun 1999 tanggal 23 September 1999 Tentang Pers yang isinya antara lain menegaskan bahwa terhadap pers nasional tidak diperbolehkan lagi adanya penyensoran, pembredelan atau pelarangan penyiaran. Ditegaskan pula bahwa pers nasional mempunyai fungsi sebagai media infomasi, pendidikan, hiburan dan kontrol sosial, di samping dapat berfungsi sebagai lembaga ekonomi. Dengan kata lain, insan pers di Indonesia dituntut untuk memenuhi Kode Etik Jurnalistik (KEJ) dan mentaati Undang-undang Pers No. 40 tahun 1999 serta ketentuan dan kaidah hukum yang berlaku di Tanah Air agar ekses-ekses dan sensasionalisme yang menyertai kebebasan pers dapat dihindari. 
Meski di tengah keterpurukan ekonomi yang diperparah dengan terjadinya tragedi 11 September 2001 di Amerika Serikat yang menyebabkan terguncangnya perekonomian global, industri pers di Indonesia sendiri secara kuantitatif mengalami perkembangan seiring berkembangnya era kebebasan pers yang ditandai naiknya jumlah dan produksi koran, majalah dan tabloid, bahkan munculnya stasiun-stasiun televisi dan radio swasta. Perkembangan media massa setelah era reformasi seakan-akan berlomba dengan naiknya jumlah partai-partai politik baru di Indonesia. Keduanya menjadi ekspressi dan bukti hadirnya kebebasan pers dan demokrasi di Tanah Air .

Tapi dalam beberapa tahun terakhir ini media online berkembang pesat di seluruh dunia, termasuk di Indonesia, didorong oleh semakin majunya teknologi informasi yang ternyata kemudian menyebabkan banyak media cetak "gulung tikar" dan beralih ke edisi online. Di sisi lain, di kalangan masyarakat berkembang apa yang disebut citizen journalism (jurnalisme warga). Citizen Journalism adalah aktivitas jurnalistik yang dilakukan oleh warga biasa (yang bukan wartawan). Jurnalisme warga ini mempunyai peran aktif dalam proses pengumpulan, pelaporan, analisis, dan penyebaran berita serta informasi. Tipe jurnalisme ini menjadi sebuah tren baru bagaimana warga bisa membuat dan menyebarkan informasi dalam bentuk teks, audio, komentar dan analisis.

Dari penjelasan di atas, nampak bahwa perkembangan politik dan regulasi pers serta kemajuan teknologi informasi pada dasarnya telah memberikan tantangan terhadap perusahaan pers dan informasi untuk maju dan berkembang sesuai kemampuan masing-masing. Media massa, termasuk Kantor Berita ANTARA dituntut supaya melakukan terobosan-terobosan baru, termasuk dalam kerjasamanya dengan mitra-mitra asing serta harus pandai membaca tanda-tanda zaman dalam upaya memelihara kelangsungan hidup serta meningkatkan kemampuanya di masa depan, sepanjang tidak melanggar ketentuan dan kaidah hukum yang berlaku di Tanah Air.

Tantangan di era konvergensi media juga membuat miris ANTARA. Kantor berita itu tidak akan bisa lagi mengandalkan pendapatan dari bisnis berita mengingat semua orang bisa dengan mudah mendapatkan informasi tanpa harus mengeluarkan uang mereka. Dalam kaitan itu pula ANTARA dituntut supaya melakukan revitalisasi, termasuk menyesuaikan bentuk badan hukumnya agar kantor berita yang sejak 2007 berbadan hukum Perusahan Umum (Perum) dan berada dibawah koordinasi Kementerian Badan Usaha Milik Negara (BUMN) itu dapat bergerak lincah dan dinamis sesuai perkembangan zaman dan sesuai kemajuan teknologi informasi.

Secara filosofis revitalisasi berarti mengangkat kembali semangat segenap personil ANTARA agar mereka dapat melakukan terobosan secara inovatif, kreatif dan kompetitif di era konvergensi media saat ini. ANTARA dituntut untuk terus berusaha mencari bentuk dan posisinya yang paling tepat sebagai bagian penting dalam gerak demokratisasi dan reformasi yang berlangsung di negeri ini. ANTARA di era konvergensi media ini dituntut untuk melakukan revitalisasi dengan mengupgrade segenap SDM-nya di semua lini, baik di kalangan wartawan maupun karyawan non Redaksi. Revitalisasi sangat penting dalam upaya mempertahankan eksistensi, bahkan meningkatkan citra ANTARA sebagai kantor berita terpercaya tanpa meninggalkan idealisme sebagaimana diamanatkan para pendirinya.

Model manajemen yang birokratis di lingkungan ANTARA juga harus diubah dengan spirit dan value profesional. Harus dibangun budaya kerja modern yang berbasis profesionalisme, ethic dan moral 
dengan terus memberikan perhatian pada perkembangan teknologi yang cepat di era konvergensi media ini. Di sisi lain, dalam batas-batas tertentu, fatsun pemberitaan ANTARA setelah berbadan hukum Perum adalah uang, dalam pengertian kebebasan pemberitaan kantor berita itu menjadi "terkendala" oleh adanya ketentuan yang terkait dengan kebijakan Public Service Obligation (PSO). Dengan adanya kebijakan itu, jika ANTARA menyiarkan berita yang isinya mengeritik pemerintah, maka dana PSO dipastikan tidak akan cair atau tidak akan dibayarkan kepada ANTARA.

Oleh karena itu perlu dilakukan penggalian dana secara optimal dari produk asli untuk mendukung opersionalisasi ANTARA, sebab kebergantungan pada dana dari Pemerintah berupa dana PSO tidak akan mempercepat kemandirian kantor berita tersebut, sementara kemandirian adalah salah satu prinsip penting dari Good Corporate Governance (GCG). Dalam kaitan itu pula perlu diterapkannya strategi bisnis dengan mengedepankan efisiensi dan efektivitas serta dengan memperkaya variasi produk informasi ANTARA. Produk dimaksud perlu dikemas dalam beragam bentuk inovasi yang menarik, baik dalam bentuk teks, foto, audio, visual maupun audio visual serta online. Pengemasan aneka produk berita secara menarik diyakini akan memberikan dampak signifikan bagi kemajuan ANTARA ke depan (Primayanti, 2015).

Sesuai peran kesejarahannya bagi negara, ANTARA ke depan juga perlu melaksanakan fungsi diplomasi publik dalam upaya meningkatkan citra Indonesia di dunia internasional. Dedikasi dan loyalitas ANTARA sejatinya adalah bukan kepada pemerintah (penguasa), melainkan harus kepada negara, dalam hal ini NKRI. Keberpihakan ANTARA harus didedikasikan untuk membela kepentingan negara dan bangsa serta bukan kepentingan pemerintah (penguasa) atau golongan tertentu. Oleh karena itu ideologi media kantor berita tersebut serta penjabarannya dalam kebijakan pemberitaan yang mengedepankan kepentingan bangsa dan negara harus disosialisasikan dengan benar kepada segenap wartawannya, sehingga framing pemberitaannya pun akan menjadi jelas dan sesuai dengan kebijakan yang ada.

\section{SIMPULAN}

Berdasarkan penelitian dan pembahasan tentang kebijakan pemberitaan ANTARA di atas, dapat disimpulkan bahwa, Pertama, Dari sisi Pemerintahan Orde Lama (1945-1965), media massa khususnya ANTARA cenderung menjadi corong pemerintah. Sementara itu pada era Orde Baru tampak bahwa kebijakan pemerintah terhadap pers pada periode 1966 hingga 1974 relatif terbuka dan bebas, sehingga masa itu disebut sebagai "masa bulan madu" antara Soeharto dan jajaran pers. Sebelumnya Soeharto membredel sejumlah koran komunis dan melakukan pembersihan besar-besaran terhadap wartawan berhaluan komunis. Kedua, Setelah peristiwa 15 Januari (Malari) 1974 hingga 1988 Pemerintahan Orde Baru mengubah secara drastis kebijakannya terhadap pers, dari bersikap longgar ke sikap keras, ditandai dengan banyaknya pembredelan surat-surat khabar. Sementara itu sejak 1989 hingga 1998 sikap keras Pemerintah Orde Baru terhadap pers nasional relatif melunak dan kontrolnya relatif melemah. Sedangkan sejak runtuhnya Pemerintah Orde Baru (sejak 1998 hingga saat ini) pers Indonesia cenderung bebas kebablasan. Ketiga, Kemudian framing pemberitaan ANTARA dipengaruhi oleh faktor eksternal (terutama kebijakan pemerintah) dan faktor internal kantor berita itu sendiri. Framing pemberitaan ANTARA di era reformasi bersifat bebas dan independen, asalkan tidak menyudutkan pemerintah, sedangkan 
di era Orde Lama dan Orde Baru cenderung "diarahkan" oleh pemerintah di masa itu.

\section{DAFTAR PUSTAKA}

Barrett, O. B. (2015). Media Imperialism. Sage Publications.

Berger, A. A. (2016). Media and Communication Research Methods: An Introduction to Qualitative and Quantitative Approaches. In Journal of Chemical Information and Modeling (Fourth Edi, Vol. 53, Nomor 9). Sage Publications.

https://doi.org/10.1017/CBO97811074 15324.004

Chakravarty, S. R., Mitra, M., \& Sarkar, P. (2016). A Course on Cooperative Game Theory. Cambridge University Press.

Damanik, M. P., \& Purwaningsih, E. H. (2018). Kesiapan E-Government Pemerintah Daerah Menuju Pengembangan Smart Province (Studi Pada Pemerintah Kabupaten Mandailing Natal, Provinsi Sumatera Utara) E-Government Readiness On Local Government Towards Development Of Smart Province ( Study On Mandailin. Jurnal Studi Komunikasi dan Media, 22(2), 185196.

https://doi.org/http://dx.doi.org/10.314 45/jskm.2018.220207

Eriyanto. (2011). Analisis Wacana; Pengantar Analisis Teks Media. LKiS.

Ferandy, M. (2016). Sejarah Reuters: Perusahaan Agen Berita yang Memengaruhi Dunia dan Menggerakkan Pasar. satujam.com. https://satujam.com/sejarah-reuters/

Friedman, Th. L. (2019). Hot, Flat, and Crowded 2.0: Why We Need a Green Revolution--and How It Can Renew America. Picador.

Hamad, I. (2004). Konstruksi realitas politik dalam media massa: sebuah studi critical discourse analysis terhadap berita-berita politik. granit.

Itule, B. D., \& Anderson, D. A. (2004). News writing and reporting for today's media. McGraw-Hill.

Khadziq, K. (2016). Media Convergence of Local Newspapers: Descriptive Study of Internet Utilization in Jogja Tribune Newspapers in Building Local Print Media Industry. (Konvergensi Media Surat Kabar Lokal: Studi Deskriptif Pemanfaatan Internet Pada Koran Tribun Jogja Dalam . Profetik: Jurnal Komunikasi, 9(1), 5-20. https://doi.org/10.14421/pjk.v9i1.1187

Lestari, P., Prabowo, A., Ishak, A., Junaedi, F., HH, S. B., \& Widodo, Y. (Ed.). (2012). Komunikasi Militer. ASPIKOM.

Mulyana, D. (2018). Metodologi Penelitian Kualitatif: Paradigma Baru Ilmu Komunikasi dan Ilmu Sosial Lainnya. PT Remaja Rosdakarya.

Primayanti. (2015). Kajian Manajemen Produksi Pemberitaan PSO Bidang Pers Oleh LKBN ANTARA. Jurnal Visi Komunikasi, 14(01), 75-89. https://doi.org/https://dx.doi.org/10.22 441/jvk.v14i1.1667

Putri, C. E., \& Hamzah, R. E. (2018). Convergence of Popular Magazine Content in the Digital Media Print Industry (Konvergensi Konten Majalah Popular dalam Industri Digital Media Cetak). Warta ISKI, 1(02), 19-28. https://doi.org/10.25008/wartaiski.v1i0 2.14

Ritonga, R. (2001). Pers dan integrasi nasional: (suatu studi tentang intervensi pemerintahan orde baru terhadap pemberitaan LKBN Antara untuk mempertahankan integrasi nasional). Perpustakaan nasional RI. 